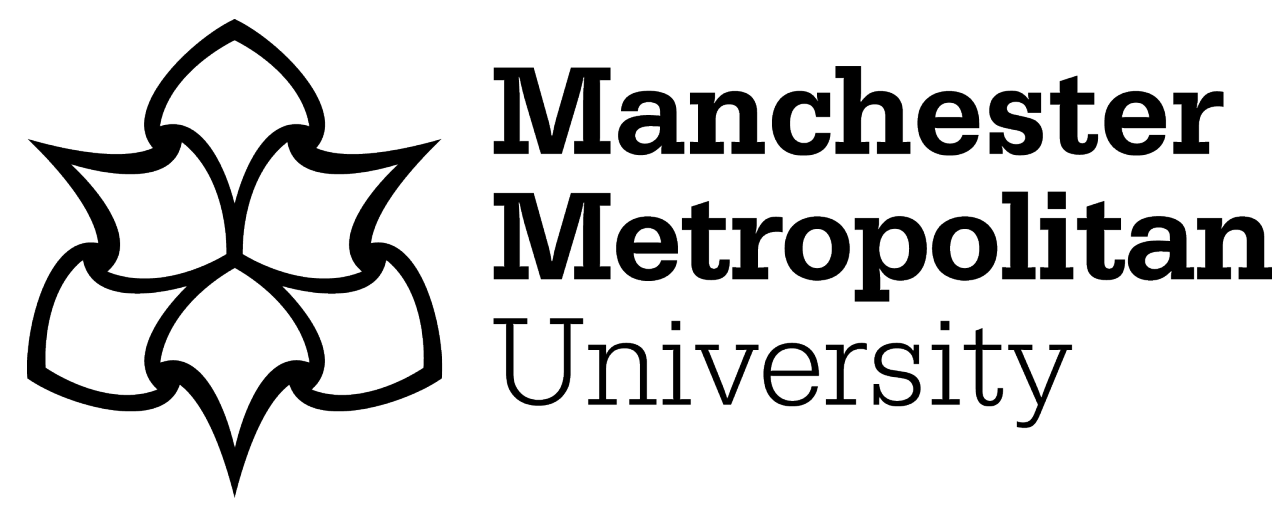

Strickland, L (2016) Leibniz's Harmony between the Kingdoms of Nature and Grace. Archiv für Geschichte der Philosophie, 98 (3). pp. 302-329. ISSN 1613-0650

Downloaded from: https://e-space.mmu.ac.uk/141/

Version: Accepted Version

Publisher: De Gruyter

DOI: https://doi.org/10.1515/agph-2016-0014

Please cite the published version 


\title{
Leibniz's Harmony between the Kingdoms of Nature and Grace
}

\begin{abstract}
One of the more exotic and mysterious features of Leibniz's later philosophical writings is the harmony between the kingdom of nature and the kingdom of grace. In this paper I show that this harmony is not a single doctrine, but rather a compilation of two doctrines, namely (1) that the order of nature makes possible the rewards and punishments of rational souls, and (2) that the rewards and punishments of rational souls are administered naturally. I argue that the harmony is best considered as Leibniz's distinctive collation, development, and rebranding of these doctrines, which were not themselves unique to Leibniz, nor uncommon in the seventeenth century. There follows a detailed examination of various concrete examples of the harmony in operation, from which I show that it is essentially the culmination of Leibniz's lifelong thinking about divine justice.
\end{abstract}

Lloyd Strickland: Department of History, Politics, and Philosophy, Manchester Metropolitan University, Geoffrey Manton Building, Manchester, M15 6LL, UK L.Strickland@mmu.ac.uk

\section{Introduction}

In his mature philosophy, Leibniz identifies no fewer than three harmonies embedded into creation: that between minds and bodies, that between efficient causes and final causes, and that between the kingdom of nature and the kingdom of grace. ${ }^{1}$ The first holds that minds and bodies do not interact but that their respective states nevertheless conspire through the operation of their own distinct laws. ${ }^{2}$ The second holds that any natural effect can be equally well explained with reference to teleological laws (and hence final causes) as to mechanistic laws (and efficient causes), even though the two sets of laws (and causes) do not overlap or

\footnotetext{
${ }^{1}$ In $\S 46$ of the Causa Dei (1710), Leibniz identifies the three harmonies as "formal causes, or souls, with material causes, or bodies; efficient or natural causes with final or moral causes; the kingdom of grace with the kingdom of nature”. G VI, 446. All the translations of Leibniz's writings in this paper are mine. Where possible, I have cited a published translation that has informed my own.

${ }^{2}$ See for example "A new system on the nature and the communication of substances" (1695), G IV, 477487/SLT 68-77.
} 
interfere. $^{3}$ And the third holds that there is a concord between God's roles as architect of the physical universe, and his role as monarch of the moral universe of minds, such that his plans for minds are effected through the order of nature. ${ }^{4}$ Each and every one of the realms in these three harmonies is inviolable, and so is not affected or influenced by whatever happens in its counterpart, but because of God's masterful organization at the outset to make them conspire, it will look to us as if there is influence between them. The decision to embed so many harmonies into creation is an upshot of God's perfect wisdom, which is irresistibly drawn to harmony. ${ }^{5}$ According to Leibniz, "supreme wisdom and goodness can act only with a perfect harmony", 6 and consequently "everything God does is harmonious to perfection". 7 This ensures that if there is an aspect of creation which could be made harmonious, then God will make it so. ${ }^{8}$

Of the three harmonies recognized by Leibniz, that between the kingdoms of nature and grace is the one most neglected by commentators. Writings of a good length on it are few and far between; the most detailed to date is a book chapter written in 1973 by Christian Zangger, though this omits much that is important. ${ }^{9}$ More often, the harmony is mentioned in commentators' works only in passing, usually in a handful of pages, and sometimes even less. ${ }^{10}$ Such brief treatments inevitably overlook many of the aspects or facets of this harmony. As one of Leibniz's signature doctrines, a detailed elucidation of this harmony is long overdue, and will be the focus of this paper. In what follows I aim to establish two main points. First, through an elucidation of this harmony in section 2, I show that it is best

\footnotetext{
${ }^{3}$ See for example “Tentamen anagogicum” (c. 1696), G VII, 290-297/L 477-484.

${ }^{4}$ Hence there is a "harmony between the physical kingdom of nature and the moral kingdom of grace; that is, between God as architect of the machine of the universe, and God considered as monarch of the divine city of minds”. Monadology (1714) G VI, 622/LM 32.

${ }^{5}$ Leibniz writes in 1671: "since God is the most perfect mind, it is impossible that he is not affected by the most perfect harmony". Letter to Magnus Wedderkopf (May 1671), A II 1, 186/L146.

${ }^{6}$ Principles of Nature and Grace (1714), G VI, 604/LM 275.

${ }^{7}$ Theodicy (1710), G VI, 142/H 162.

${ }^{8}$ Hence: "All is connected in nature; and if a skilled artisan, an engineer, an architect, a wise politician often makes one and the same thing serve several ends, if he kills two birds with one stone, when that can be done conveniently, it may be said that God, whose wisdom and power are perfect, does so always." G VI, 169/H 189. In another text, Leibniz claims that God "produces infinite harmonies", though whether this should be taken literally is unclear. See his letter to Christian Wolff (18 May 1715) in W 171/AG 233.

${ }^{9}$ Zangger 1973, 39-49. Worth noting here also is Phemister 2003, though this paper is concerned more with the composition of the two kingdoms rather than the harmony between them, about which very little is said.

10 The best of these is Adams 1994, 82-85.
} 
considered as Leibniz's collation, development, and rebranding of two doctrines that were by no means uncommon in his day, both of which concern the natural distribution of rewards and punishments. Second, from a detailed examination of various concrete examples of the harmony in section 3, I show that the harmony between the kingdoms of nature and grace is essentially the culmination of Leibniz's lifelong thinking about divine justice, since the harmony is concerned exclusively with the dispensation of rewards and punishments, throughout this life and the next, using natural means alone. To bolster that claim, I consider a Leibnizian doctrine that one might think should fall under the harmony, but which apparently does not, namely the natural distribution of grace. This might be thought surprising, in that it means Leibniz's harmony between the kingdoms of nature and grace actually has nothing to do with grace, in spite of its name. I conclude by speculating on why Leibniz apparently excluded grace from this harmony.

\section{The harmony between the kingdoms of nature and grace}

References to the harmony between the kingdoms of nature and grace are commonly found in Leibniz's later writings; as far as I have been able to determine, Leibniz first refers to it in a letter written in June $1710 .{ }^{11}$ In a text written less than a year before that, in July 1709 , Leibniz identifies only two parallelisms, or harmonies: the one between body and soul, and the other between the kingdom of efficient causes and the kingdom of final causes. ${ }^{12}$ This suggests that the identification of the third parallelism, between the kingdoms of nature and grace, was made either in the second half of 1709 or in the first half of 1710 . This is the time in which Leibniz was completing the Theodicy, the first edition of which was published in the last months of 1710. The harmony between the kingdoms of nature and grace makes several appearances in that book, and then features in many of Leibniz's most important philosophical writings thereafter, such as the Monadology (1714) and the Principles of Nature and Grace (1714). Yet as we shall see as we proceed, the "harmony between the kingdoms of nature and grace" is a compilation of two distinct but related doctrines, both of which had been present in Leibniz's writings prior to 1709/10. Consequently, this particular harmony is best viewed as the outcome of a restructuring and rebranding exercise that

\footnotetext{
${ }^{11}$ To Wagner (4 June 1710), in D II:1, 226-230.

${ }^{12}$ See "Animadversiones circa assertiones aliquas theorie medicae verae Clar. Stahlii" (24 July 1709), D II:2, 133.
} 
Leibniz undertook in 1709/10 rather than the introduction into his philosophy of something new. ${ }^{13}$

What, then, are these constitutive doctrines? Or to put it another way, what does the harmony between the kingdoms of nature and grace actually involve? In his writings on the subject, Leibniz takes the harmony to comprise the following two doctrines:

HNG1: That the order of nature makes possible the rewards and punishments of rational souls (by making all souls naturally indestructible, and in addition ensuring that rational souls will retain their memory and personality)

HNG2: That the rewards and punishments of rational souls are administered naturally, such that each act of virtue or vice naturally brings about its own reward or punishment

Although complementary, the two doctrines are logically independent, in that it is perfectly possible to accept either one while rejecting the other, and in fact it is likely that Leibniz came to endorse them at different times in his career: as we shall see, HNG1 is in place by the mid-1680s, and HNG2 by the mid-1690s. Nevertheless, what Leibniz does in 1709 or 1710 is fuse the two complementary doctrines into a stable compound, and calls it the harmony between the kingdoms of nature and grace. Curiously, however, even when he has done this, he continues to treat the elements of this compound in isolation, for when he discusses the harmony between the two kingdoms he typically goes on to discuss either HNG1 or HNG2, but not both together. This is the distribution of the two doctrines across the principal works in which the harmony is discussed: ${ }^{14}$

\section{Text}

Doctrine endorsed as example of harmony between the kingdoms of nature and grace

\footnotetext{
${ }^{13}$ In a text from 1694, Leibniz makes passing reference to the "moral kingdom of minds and the mechanical kingdom of bodies", though he does not explain what he means by these terms, nor does he associate any doctrines with them. See Leibniz's notes on Seder Olam (1694), unpublished manuscript held in the Gottfried Wilhelm Leibniz Bibliothek, shelf mark LH I, V, 2, B1. 22. A deleted passage reveals that he originally described the "moral kingdom of minds" as "the kingdom of reason and minds".

${ }^{14}$ The same is true of the minor works in which the harmony of the kingdoms of nature and grace is discussed, i.e. letters; in each case, Leibniz discusses HNG1 or HNG2 but not both.
} 


\begin{tabular}{|ll|}
\hline On the souls of men and beasts (1710) & HNG1 \\
\hline Theodicy (1710) & HNG1, HNG2 \\
\hline Causa Dei (1710) & HNG2 \\
\hline $\begin{array}{l}\text { Metaphysical consequences of the principle of } \\
\text { reason (1712) }\end{array}$ & HNG1 \\
\hline Monadology (1714) & HNG2 \\
\hline Principles of nature and grace (1714) & HNG2 \\
\hline
\end{tabular}

While the Theodicy looks to be an exception, in fact it is not. It is a lengthy work, and Leibniz returns to the harmony between the two kingdoms numerous times during the course of it, and each time he does so he discusses either HNG1 or HNG2, but not both together. I have no explanation for why Leibniz would keep them separate, especially since the two doctrines are clearly connected.

We turn now to an examination of the two doctrines.

\subsection{HNGI. Natural indestructibility and the immortality of rational souls}

We begin with the first of the two, which holds that the order of nature makes possible the rewards and punishments of rational souls. This claim can be found in Leibniz's so-called “middle period". For example, in a letter to Arnauld from 1687, Leibniz writes:

And one may truly be assured that the whole universe has been made only to contribute to the ornament and goodness of this City of God. This is why everything is arranged in such a way that the laws of force, or purely material laws, conspire in all the universe to carry out the laws of justice or of love, that nothing can harm souls, which are in God's hand, and that everything must work for the greatest good of those who love him. This is why minds must preserve their personalities and their moral qualities, in order that the City of God loses no one. It must be that they preserve in particular a kind of reminiscence, or consciousness, or the power to know what they are, upon which all their morality, penalties, and punishments depend. $^{15}$

The claim here was subsequently repeated in many of Leibniz's writings, and in 1710 he identified it as an instance of the harmony between the kingdoms of nature and grace:

\footnotetext{
${ }^{15}$ To Arnauld (9 October 1687), A II 2, 257-258/L 347, cf. A II 2, 260/L348.
} 
Finally, man is assigned by God to a much higher end, namely, to a society with him; and therefore (on account of the harmony of the kingdoms of nature and grace) it has been established that human souls are preserved together with some organic body, not only in the manner of beasts, which are perhaps stupefied for a time after death, but in a more noble way, so that they retain sensation and consciousness and are capable of punishment and reward. ${ }^{16}$

The seventeenth century was awash with philosophers who argued that the soul was naturally immortal, most famously Descartes in the Meditations,${ }^{17}$ but also many of those who followed him, such as Malebranche, ${ }^{18}$ and Le Grand. ${ }^{19}$ The most common tactic was to stress that the soul is lacking in extension, and is therefore inherently indivisible, and as such not subject to dissolution or corruption. Because of this, it was argued, the only means of destroying an indivisible thing would be by annihilation, that is, by actually deleting it from existence, but as this would be a supernatural process of destruction, rather than a natural one, it must therefore be the case that souls are immortal by nature. Despite the popularity of this argument among his contemporaries, Leibniz frequently complained that it only yields the conclusion that souls are naturally indestructible. ${ }^{20}$ True immortality, he insisted, requires not just the preservation of our substance: it also requires the preservation of our person. ${ }^{21}$ Hence a truly immortal soul will endure forever, retaining its memory and its personality. Animal souls, which do not retain these things, can be said to be indestructible (as are all souls), ${ }^{22}$ but not immortal (a privilege granted only to rational souls):

I think that beasts have an incorporeal soul, and that it will not perish, although it does not deserve to be called immortal, because it does not retain the same personality, as does a human soul, which preserves knowledge of deeds done, that is, its own memory, and therefore is capable of rewards and punishments beyond this life. ${ }^{23}$

\footnotetext{
16 "On the souls of men and beasts" (1710), G VII, 332/SLT 67.

${ }^{17}$ See Descartes 1984, 10.

${ }^{18}$ Malebranche 1997b, 274.

${ }^{19}$ Le Grand 1678, 512.

${ }^{20}$ See for example A II 1, 779-780.

${ }^{21}$ See "Discourse on Metaphysics" (1686), A VI 4, 1584/L 326.

${ }^{22}$ The difference between animal souls and human souls, Leibniz explains to one correspondent, is that while both are "physically immortal", only the latter are "morally immortal". To Kortholt (17 June 1712), D V, 320.

${ }^{23}$ To Kortholt (15 March 1713), D V, 320-321.
} 
Humans are members of God's moral society (the "City of God"), and as such are morally accountable for what they do. Justice demands that they be rewarded or punished accordingly for their good and bad actions, and since this tends not happen in this life (in which the good often suffer and the wicked often prosper), human existence must continue after this life in order that the balance of reward or punishment due may be settled. But for true justice to be done it is not enough that humans continue to exist after this life: they must also retain their memory and their personality. And according to Leibniz, this all-important preservation of memory and personality does occur, and occurs naturally, without any intervention from God. So here, the kingdom of nature harmonizes with that of grace, with the former preserving the very things whose preservation is required by the latter:

But since nature gradually dispels confusions, then that which we imagine to be death cannot be perpetual. Moreover, rational substances alone preserve not only their own individuality but also their personality, retaining or recovering consciousness of themselves, so that they can be citizens in the city of God, capable of reward and punishment. Thus in their case, the kingdom of nature serves the kingdom of grace. ${ }^{24}$

Leibniz does not explain how memory and/or personality is naturally preserved, but arguably does not need to do so since he has strong a priori reasons for thinking that there is such an explanation (namely that God's wisdom will instantiate a harmony between the kingdoms of nature and grace, which requires the natural preservation of the memory and personality of human souls), so consequently he knows that there must be such an explanation even if the detail of it lies out of reach. ${ }^{25}$

\subsection{HNG2: The natural distribution of punishment and reward}

It goes without saying that while the preservation of human beings, personality and all, makes possible the future dispensation of rewards and punishments, it does not itself entail that the dispensation will actually occur, or determine how rewards and punishments will be dispensed if they are dispensed. Such concerns were addressed in the second doctrine that was encompassed within Leibniz's harmony between the two kingdoms; this doctrine insists that the rewards and punishments of rational souls are administered naturally, such that each act of virtue or vice naturally brings about its own reward or punishment. The following

\footnotetext{
24 "Metaphysical consequences of the principle of reason" (1712), C 16/P 177.

${ }^{25}$ Leibniz reasons in precisely this way; see his letter to Sophie (29 November 1707), K IX, 287-288/LTS 363.
} 
passage, from the essay Principles of Nature and Grace (1714), is a typical summary of this doctrine:

all minds, whether of men or genies [...] are [...] members of the City of God, that is, the most perfect state, formed and governed by the greatest and best of monarchs, in which there is no crime without punishment, no good actions without proportionate reward, and finally as much virtue and happiness as is possible. And this comes to pass not by any disruption of nature, as if what God has in store for souls might disturb the laws of bodies, but by the very order of natural things, in virtue of the harmony pre-established from all time between the kingdoms of nature and grace, between God as architect and God as monarch, in such a way that nature itself leads to grace, and grace perfects nature by making use of it. ${ }^{26}$

There are two distinct claims here:

(a) That every virtuous act will be rewarded and every sinful act punished

(b) That rewards and punishments will be administered naturally

Leibniz sometimes makes both claims together when discussing the harmony of the two kingdoms, although strictly speaking only (b) is a consequence of this harmony (while (a) is a consequence of God's perfect justice). In some writings Leibniz endorses (a) without mentioning (b) at all, ${ }^{27}$ and it is likely that for a not inconsiderable part of his career he accepted (a) but not (b); this is unproblematic inasmuch as either claim can be accepted without the other.

The core claim of HG2, then, is that rewards and punishments will be administered naturally. But how are we to understand this? A number of answers seem possible:

One possible answer is what might be termed reflexive punishment, where a sin just is its own punishment, for example the sin of distancing oneself from God is its own punishment.

\footnotetext{
${ }^{26}$ G VI, 605/LM 276.

${ }^{27}$ For example, "Memoir for enlightened persons of good intention" (c. 1692), A IV 4, 614/R 105; Letter to Placcius (29 September 1697), D VI 84; "Considerations on vital principles and plastic natures" (1705), G VI, 545/L 590 .
} 
A second possibility is that a sin is connected to its own punishment by a straightforward process of cause and effect, such that, given the prevailing laws of nature, if the sin occurs, then the punishment must follow. We might call this nomic punishment.

A third possible answer is that sins naturally attract their punishment. Here the connection between sin and punishment is forged through the reactions of moral agents: a sin galvanizes or inspires such agents to mete out punishment, and thus draws down punishment on itself. A good illustration of this can be found in an example of Kant's, where "a man who delights in annoying and vexing peaceable people at last receives a right good beating". ${ }^{28}$ Let us term this agential punishment.

Among those who have examined Leibniz's doctrine of natural punishment, there is little agreement as to what it amounts to. Some commentators have claimed that Leibniz sees natural punishment as (exclusively) reflexive punishment, ${ }^{29}$ while others have claimed that he sees it as (exclusively) nomic. ${ }^{30}$ Neither camp is correct, as we shall see. It is certainly true that Leibniz endorsed reflexive punishment, or something very much like it, but only in one specific case, namely the distancing of oneself from God:

But just as a man who does not know a good doctor is punished enough for that, because he does not get cured, so it can happen for the same reason that those who do not know the perfections of the divinity punish themselves, because they do not derive the assistance that they could expect from this knowledge. ${ }^{31}$

Much more popular among commentators is the view that Leibniz's natural punishment is (exclusively) nomic punishment. But those who have taken this line have struggled to identify examples of it in Leibniz's writings, ${ }^{32}$ and some have even tried, without success, to ascertain how nomic punishment could work in Leibniz's philosophy. ${ }^{33}$ Scholarly disagreements and uncertainties like those just described are usually due to a primary literature which is ambiguous, opaque, or lacking in detail, and there is a little of that here. Certainly some of Leibniz's remarks on the natural punishment of sins do not obviously point

\footnotetext{
${ }^{28}$ Kant 1996, 80.

${ }^{29}$ See for example Sève 1989, 120; Mormino 2009, $40 \mathrm{ff}$.

${ }^{30}$ See, for example, Fabre 1907, 506; Broad 1975, 170; Carlin 2002, 155.

${ }^{31}$ Appendix to a letter to Coste (1711), G III, 415.

32 See for example Woolhouse 2011, 118.

${ }^{33}$ See Carlin 2002, $143 \mathrm{ff}$.
} 
to any one of the methods of natural punishment just outlined over another; for example, his claim that "sins naturally trail their punishment after them by a kind of pre-established harmony", ${ }^{34}$ could plausibly be construed in terms of reflexive, nomic, or agential punishment. In some writings, however, Leibniz appears to lean towards the method identified above as nomic punishment. For example, in the Monadology (1714) he writes:

It can also be said that God as architect satisfies in every way God as legislator, and that sins must therefore carry their punishment with them by the order of nature, and by virtue of the mechanical structure of things itself, and that likewise good actions will receive their rewards by ways which are mechanical with regard to bodies, although this cannot and need not always happen immediately. ${ }^{35}$

Meanwhile, in other remarks, Leibniz uses the language of attraction, which I have associated with agential punishment:

the principle of fitness [...] has made it the case that things have been ordered in such a way that the bad action should bring upon itself a punishment. There are grounds to conclude, following the parallelism of the two kingdoms, that of final causes and that of efficient causes, that God has established in the universe a connection between punishment or reward, and between bad or good action, such that the first should always be attracted by the second, and that virtue and vice obtain their reward and their punishment as a result of the natural series of things, which contains yet another kind of pre-established harmony than that which is apparent in the commerce between the soul and the body. For in a word, everything God does is harmonious to perfection. ${ }^{36}$

Leibniz in fact accepted both nomic punishment and agential punishment in his account of the natural punishment of sins, though demonstrating this will require a detailed examination of Leibniz's doctrine of natural rewards and punishments. This task is worthwhile in its own right, as it will also reveal the historical dimension of Leibniz's theodicy, a side of it that is often overlooked. ${ }^{37}$ It is thus to this task that we now turn.

\footnotetext{
${ }^{34}$ Appendix to a letter to Coste (1711), G III, 414.

${ }^{35} \mathrm{G}$ VI, 622/LM 32

${ }^{36}$ G VI, 142/H 162.

${ }^{37}$ For example by John Hick, who erroneously takes Leibniz's claim that ours is the best possible world to exclude the denouement of human history in the afterlife. See Hick 2010, 81.
} 


\section{Administering rewards and punishments through the order of nature}

In examining the claim that rewards and punishments are distributed naturally, we will often find ourselves focusing on punishments, as this is what Leibniz himself tends to do. A clue as to Leibniz's inspiration for his belief that sins are naturally punished can be found in a letter to a correspondent in 1695: "I told you yesterday, Sir, that according to the ancients every sin punishes itself." ${ }^{38}$ Unfortunately Leibniz does not say which of the ancients he has in mind, but certainly the idea that evil punishes itself has a rich history. Variations of this theme can be found in the Old and New Testaments, ${ }^{39}$ the Church Fathers, ${ }^{40}$ as well as respected secular authors such as Seneca. ${ }^{41}$ Yet in endorsing the notion of natural punishment, it is far from clear that Leibniz is simply throwing his weight behind traditional thinking. In fact, the doctrine as he espouses it would very likely strike many Christians as somewhat heterodox, even though Leibniz sometimes connects it with traditional Christian doctrines.

\subsection{Original sin}

This is the case with our first example of the natural punishment of sin, which is discussed in the Theodicy: Adam's original sin of eating the forbidden fruit, which thereby brought corruption upon the whole of his posterity. Leibniz notes that the traditional account has it that God, justifiably annoyed by Adam's transgression, deliberately intervened to impose punishment by corrupting both him and his offspring. Leibniz disagreed, insisting:

There are grounds to think that the forbidden action by itself entailed these evil effects by virtue of a natural consequence, and that it was for that very reason, and not by a purely arbitrary decree, that God had forbidden it, rather as one forbids knives to children. ${ }^{42}$

Leibniz's preference for an alternative account emerges from "contemplation of divine wisdom [which] leads us to believe that the Kingdom of nature serves that of grace; and that God as Architect has done everything as befitted God considered as Monarch."43 But while

\footnotetext{
${ }^{38}$ To Baron Friedrich Boguslaus Dobrzensky (26 January 1695), Gr I, 369.

${ }^{39}$ See for example Jeremiah 2.19; John 5.14; Galatians 6.7.

${ }^{40}$ Augustine 2012, 21 (I.12.19).

${ }^{41}$ See Seneca 1786, 85 and 200 (letters 87 and 95).

${ }^{42}$ G VI, 164/H 184.

${ }^{43}$ G VI, 164-5/H 185.
} 
Leibniz is able to draw from God's wisdom the conclusion that Adam's punishment was naturally administered, he did not think it possible to ascertain exactly how: "We do not sufficiently know the nature of the forbidden fruit, or that of the action, or its effects, to judge the detail of the matter." 44 In his discussion of the natural transmission of original sin Leibniz mentions only Robert Fludd's suggestion that the fruit eaten by Adam contained a poison (such a level of detail is unobtainable, Leibniz complains in response), ${ }^{45}$ but his own view is closer to that advanced by two of the early Church Fathers, namely Tertullian and Augustine. Tertullian endorsed a version of traducianism which held that an individual inherits both her soul and body from her parents, as well as her soul's spiritual characteristics; ${ }^{46}$ as such, Adam transmits not only a body and soul to each of his offspring, but also his sin and corruption as well, and his offspring in turn transmit these things to their offspring, and so on. A similar story is told by Augustine, who held that all human beings were literally present in Adam when he sinned, and therefore participated in the sin and in the penalty of corruption that God imposed in response. ${ }^{47}$ Leibniz's mechanism of choice for the natural transmission of original sin was the cognate doctrine of preformation. This holds that all animals (humans included) that were to develop throughout the course of the universe began as seeds that were present in the semen of the very first generation of the species. ${ }^{48}$ Thus Adam, as the first human, contained the seeds of every subsequent human being (barring Eve!). Each of these seeds contained not just a miniature version of a human body that would grow and develop once conception had taken place, but also its soul. And when Adam fell, all of the souls inside of him were tainted, as if by an inherited disease. In fact, Leibniz uses the language of "infection" when describing the events in the Causa Dei (1710):

There follows from the fall of the first parents the propagation of the infection, which reached into the souls of their descendants. This does not seem to be able to be explained more conveniently than by supposing that the souls of these descendants were already infected in Adam. $^{49}$

\footnotetext{
${ }^{44} \mathrm{G}$ VI, 165/H 185. The claim can also be found in a letter to Thomas Burnett (18 October 1712), G III, 324.

${ }^{45}$ See Otreb 1617.

${ }^{46}$ See Tertullian 1873, 25 and 40.

${ }^{47}$ See Augustine 1956, II.15.

${ }^{48}$ For more on Leibniz's preformationism, see Smith 2011, especially chapters 5 and 6.

${ }^{49} \mathrm{G}$ VI, 451.
} 
Malebranche had reached a similar view some years earlier, arguing that the corruption to Adam's brain was duplicated in the embryonic brains of his progeny inside him, who in turn passed it on to their progeny, and thus was original sin transmitted through the normal process of generation, like an undesirable trait that has been bred into a population with no natural means of breeding it out. ${ }^{50}$ In contrast to this, Leibniz characterized original sin as akin to an addiction to evil which is naturally transmitted from generation to generation as though it were some impossible-to-treat infection. ${ }^{51}$ And this, Leibniz believed, was an instance of nature dovetailing with grace, for "Original sin [...] is not a simple penalty for the first sin; it is a natural consequence thereof." 52 It is thus an example of nomic punishment.

\subsection{The great flood, and the final conflagration}

As indeed is our next example of the natural punishment of sins, which can be found in the Monadology:

This harmony [between the kingdoms of nature and grace] means that things lead to grace by the very ways of nature, and that for example this globe must be destroyed and repaired by natural ways at the times the government of minds demand it for the punishment of some and the reward of others. ${ }^{53}$

\footnotetext{
${ }^{50}$ See Malebranche 1997b, 120 and 582; and 1997a, 208 (section XI.X).

${ }^{51}$ While Leibniz does consider the corruption of original sin to be a punishment on Adam's progeny, he does not consider it to be a punishment worthy of damnation: "I would not venture to assert that original sin without an accompanying actual sin (in other words, in those who die before they attain the use of reason) is sufficient for damnation, which some have thought." G III, 36.

${ }^{52}$ G VI, 180/H 200. Nicholas Jolley has argued that Leibniz "seems to show some embarrassment in his treatment" of the Fall, and "betrays discomfort whenever the occasion calls for him to take a stand on the issue of human corruption through original sin". Jolley 2014, 62. My own impression, which does not differ much if at all from Jolley's, is that Leibniz is only troubled by some of the harsher interpretations of the moral repercussions of the Fall, rather than by the event itself. Certainly he recoils from the thought that, as a result of the Fall, the majority of humans (along with all unbaptized infants) will be damned, and tackles it head-on in the Theodicy. Nevertheless, in spite of his reservations about the harshness of the Fall's moral consequences for the human race, Leibniz never casts doubt on the event itself, e.g. by treating it allegorically rather than literally, and there is little doubt that he did believe in Adam and Eve, that they were the progenitors of the entire human race, that their sin had negative repercussions for all future humans etc.

${ }^{53}$ G VI, 622/LM 32.
} 
Although Leibniz does not mention either explicitly, the two most likely candidates for the planet-wide destructions mentioned here are (a) the biblical flood described in Genesis 6-9, and (b) the final destruction of the Earth prior to the Last Judgment, following which the Earth will be restored so that the blessed may enjoy eternal life under Christ's rule. ${ }^{54}$ Leibniz's geological work affords a good idea of how he envisaged the world being naturally destroyed and repaired. In the Protogaea (1691-1693), for example, Leibniz describes the formation of the Earth from an initial molten ball of fire, and the subsequent upheavals that occurred as it cooled, including earthquakes, volcanic eruptions, and great floods (of which the biblical flood was just one) of such magnitude that they submerged almost the entire surface of the Earth. But the Protogaea reveals not only that Leibniz believed that the deluges responsible for such great floods had occurred entirely through natural processes, but also that it was through natural processes alone that the waters had drained away each time. ${ }^{55} \mathrm{In}$ early modern times, naturalistic accounts of the great flood, and of the Earth's recovery from it, were not uncommon, and Leibniz's theory would not have looked out of place alongside those developed by the theologian Thomas Burnet, ${ }^{56}$ and the naturalist John Ray. ${ }^{57}$ Although each had a different view as to the mechanism responsible for the flood, they all considered the flood to be a natural event as well as a divine punishment for the sins of mankind, though in Burnet and Ray the harmony between the natural and the moral was more often insinuated than explicitly stated. Leibniz was a keen reader of works of sacred history, and knew the work of both Burnet and Ray. Yet it is just as likely that Leibniz's inspiration was Malebranche, even though the Frenchman ultimately could not bring himself to accept the naturalistic account of the flood that Leibniz so readily endorsed. In his Meditations chrestiennes (1683), Malebranche raised the possibility that the general laws of nature and the general laws of grace might work together, in the sense that the former bring to pass a natural event at the very point in which the latter morally require it. The two examples he considered were, first, that the laws of nature may have brought about the universal flood at

\footnotetext{
${ }^{54}$ Interestingly, scholars have tended to interpret Leibniz as referring to exclusively one or the other. Daniel Garber construes Leibniz's remarks as referring to the universal flood, while Anthony Savile construes them as relating to the destruction of the Earth prior to the Last Judgment. However it is worth noting Leibniz's use of the plural, which suggests that he is thinking of more than one cataclysmic event. See Garber 1995, 328; Savile 2000, 224.

${ }^{55}$ See Protogaea (1691-1693), CW 15-19.

${ }^{56}$ Burnet 1681, book 1.

${ }^{57}$ Ray $1692,63 \mathrm{ff}$.
} 
the very point at which the corruption of the human race warranted its own destruction, ${ }^{58}$ and second, that the fire which rages at the centre of the Earth may eventually increase and spill out to cause a planet-wide conflagration at the very time at which the level of human corruption requires such a destruction at the end of days. ${ }^{59}$ Yet almost as soon as the suggestions are raised, Malebranche distances himself from them, arguing that one can go too far in diminishing the number of miracles in the universe ${ }^{60}$ Leibniz, presumably, would have to disagree, since the fewer the number of miracles, i.e. direct divine interventions, the greater the harmony must be between the kingdoms of nature and grace, and as harmony is evidence of divine wisdom, the greater the harmony, the more creation befits God's supreme wisdom.

\subsection{Individual rewards and punishments}

It is notable that the specific examples of natural punishment considered thus far share two common features: (1) they all relate to key Christian doctrines, as related in various books of Scripture, and (2) they all relate to humans collectively. But for Leibniz, the harmony between the kingdoms of nature and grace encompasses not just landmark events in human history such as these, but also many particular events of each and every individual's life. This much follows from his insistence that, in the harmony between the two kingdoms, every sin is naturally punished, and every virtuous act naturally rewarded:

[In the City of God] there is no crime without punishment, no good actions without proportionate reward, and finally as much virtue and happiness as is possible. And this comes to pass not by any disruption of nature, as if what God has in store for souls might disturb the laws of bodies, but by the very order of natural things, in virtue of the harmony preestablished from all time between the kingdoms of nature and grace, between God as architect and God as monarch, in such a way that nature itself leads to grace, and grace perfects nature by making use of it. ${ }^{61}$

Now as noted earlier, when Leibniz says that sins are punished naturally, as he does here, it is common to interpret him as endorsing a form of nomic punishment. This is the thinking

\footnotetext{
${ }^{58}$ Malebranche 1683, 114-115.

${ }^{59}$ Malebranche 1683, 116.

${ }^{60}$ Malebranche 1683, 117.

${ }^{61}$ G VI, 605/LM 276.
} 
behind Roger Woolhouse's tentative suggestion that "Conceivably he [Leibniz] has in mind that an intemperate life tends naturally (though not inevitably) to unhappy pains of ill health, but what he means is not spelt out." 62 Certainly, ideas very similar to this were in circulation in Leibniz's day, and known to him. For example, John Toland argued that poverty and scorn are the natural effects of wastefulness, and may thereby be deemed the natural punishment for this sin; likewise, according to Toland, the sin of drunkenness has a number of natural effects which may be considered its punishment, namely: feeling unwell, the inability to carry out one's normal affairs, public disgrace, infamy etc. ${ }^{63}$ It is not uncommon to find Leibniz's own doctrine of natural punishment depicted (or even caricatured) in very similar ways. For example, in Voltaire's Candide, the Leibnizian character Pangloss contracts the pox from a dalliance with Paquette, ${ }^{64}$ which is very naturally read as Pangloss' (nomically-executed) punishment for giving in to his lusts. Now Leibniz was not entirely averse to identifying a direct, causal link between sin and its punishment: we have already encountered his view that there was such a link between Adam's transgression and the unfortunate effects of it being transmitted to his posterity, and we shall see a further example in due course. But Leibniz did not think that many sins were punished in this way. In fact, Leibniz often notes (and complains) that rewards and punishments are all too often left to the future life, ${ }^{65}$ which suggests that whatever the connection between sins and their punishments, it is often not as direct and immediate as in classic examples of nomic punishment such as a hangover directly caused by drunkenness. Indeed, Leibniz even claims that naturally-rewarded good actions and naturally-punished bad actions are more common in the afterlife than in this life: "During the future life especially, all sins are such that they punish themselves, and all good deeds are such that they bring about their own reward." 66

By locating much of the process of naturally-administered rewards and punishments in the afterlife, Leibniz would seem to have pushed it out of epistemological reach. He was certainly of the view that "the status of intermediate souls is an obscure matter, and one not

\footnotetext{
${ }^{62}$ Woolhouse 2011, 118.

${ }^{63}$ See "Parallele entre la raison originale ou la loy de la nature" (after 1704), Gr I, 53-54. This text survives only because Leibniz made a copy of it.

${ }^{64}$ See Voltaire 2006, 10.

${ }^{65}$ See for example Gr I, 372/SLT 205. Leibniz even claims that "it was possible for men to be atheists before revelation, since the divinity does not always avenge itself in this life". To Bierling (March 1713), D V, 391.

${ }^{66}$ To Bierling (20 October 1712), D V, 389. See also A IV 4, 614/R 105; SLT 172.
} 
sufficiently revealed by God." 67 Yet in this particular case at least, he does identify (some of) the processes involved in the posthumous distribution of rewards and punishments. He writes Wagner in 1710:

since this [the Commonwealth of God] is governed with the utmost justice and beauty, it follows that, by the laws of nature themselves, souls are rendered more suited for rewards and punishments by the force of their own actions, on account of the parallelism between the Kingdom of grace and [the Kingdom of] nature. And in this sense it may be said that virtue brings about its own reward, and crime its own punishment, because by a sort of natural consequence of the very last state of the soul, according as it departs expiated or unexpiated, there arises a sort of natural watershed, preordained in nature by God, and consistent with divine promises and threats, and with grace and justice; and also with the additional intervention of good and bad genii, according to which side we have joined. The operations of these genii are undoubtedly natural, although their nature is more sublime than ours. ${ }^{68}$

There are two distinct points made in this fascinating passage. First, that rewards and punishments are "a sort of natural consequence" of the moral status of a soul at the point of death. Second, that rewards and punishments may be administered by genii, that is, superhuman spirits such as angels and demons, whose actions (or at least those ones occurring without the assistance of God) would qualify as natural since genii are themselves part of the kingdom of nature. Let us take each of these points in turn.

First of all, what could Leibniz mean by a "natural watershed" between the expiated and unexpiated soul, that arises from "a sort of natural consequence" of its very last state? The most natural interpretation is that from the point of death onwards, the expiated soul follows a different path from the unexpiated soul, and does so as "a sort of natural consequence" of its state at death. The idea here recalls that worked out in some detail in a much earlier work, The Philosopher's Confession (1672-1673). There Leibniz details a natural psychological process whereby a damned soul brings about its own punishment. The damned soul is one which dies discontented with the world, i.e. God's work, and with God himself. This soul will carry its hatred with it into the afterlife. Between death (understood here as the separation of soul from body) and resurrection (the reunion of soul and body), the soul is disembodied, and with no sense organs to provide any new material for it to think

\footnotetext{
${ }^{67}$ To Fabricius (2/12 February 1700), A I 18, 390.

${ }^{68}$ D II: $1,229$.
} 
about, its hatred of God and his work grows stronger and stronger via a process of positive feedback:

Whoever dies malcontent dies a hater of God. And now he follows along the road on which he began, as if he were headed for the precipice; and not being held back by external things, since access to his senses has been closed off, he nourishes his soul, which has withdrawn into itself, with that hatred of things already begun, and with that misery and disdain, and with indignation, envy, and displeasure, all of them increasing more and more. $^{69}$

Unfortunately, the hatred, anger and misery of the damned person is not eased by the return of his body (and its senses) in the resurrection, because by that time his mind is so twisted that his pain is somehow pleasing to him. Consequently, after being resurrected, he will deliberately seek out things which incense him, and hence

he endlessly finds new material for contempt, disapproval, and anger; and he is the more tormented the less he can change and endure the torrent of things that are displeasing to $\operatorname{him}^{70}$

The upshot is that his hatred of God and the world continues without end, as does the torment that this hatred brings. This psychological process is described in some detail in The Philosopher's Confession, and there are allusions to it in some of Leibniz's other early works, ${ }^{71}$ but the crucial claim that the posthumous attention of the dead is focused solely on their last thoughts, does not appear to have been made again after $1686 .^{72}$ Although Leibniz's later writings do contain numerous statements about how death affects human psychological activity, they are much less detailed. The following passage is representative of Leibniz's later thought:

In death ... we do not lose life, sensation or reason, but what prevents us from noticing that for a time is the confusion, that is, the fact that at that time we have an infinity of little

\footnotetext{
${ }^{69}$ A VI 3, 142/CP 91.

${ }^{70}$ A VI 3, 142/CP 91.

${ }^{71}$ See for example D VI, 310.

${ }^{72}$ See A VI, 4, 2360/SLT 204.
} 
perceptions all at once, in which there is no single one which is clearly distinguished from the others. ${ }^{73}$

On account of this confusion of perceptions, in his later writings Leibniz routinely describes the psychological state of the dead as being akin to a "stupor", ${ }^{74}$ a claim not easily squared with there being any posthumous scrutiny of one's own sins and moral faults. Moreover, in his later writings, Leibniz consistently rejects his earlier belief in temporarily-disembodied souls: this yields to the view that all souls, even those of angels and other genii, are always embodied, and hence always attached to some organs, (the "always" here should be taken to mean: from creation onwards). ${ }^{75}$ In his later thought, then, Leibniz rejects the very aspects of his earlier thought that made possible the psychological account of posthumous selfpunishment outlined in the Philosopher's Confession, namely that souls are disembodied between death and resurrection, and that they have sufficient psychological activity during this time to dwell on their sins. Yet in spite of this, it is far from clear that the mature Leibniz entirely ruled out this psychological account, or at least something like it. For in an appendix to the Theodicy, Leibniz discusses a similar theory that had been advanced by William King in De origine mali, and says "These thoughts are not to be despised, and I have sometimes had similar ones, though I am careful not to make a decisive judgment about them." "76 It is possible, then, that in the Wagner letter of 1710, Leibniz's talk of a "natural watershed" that arises from "a sort of natural consequence of the very last state of the soul" does hark back to the psychological doctrine of posthumous self-punishment developed almost forty years earlier, or something of that order anyway. But Leibniz does not say enough to Wagner to make this interpretation secure. Indeed, it is not unreasonable to suppose that in the Wagner letter Leibniz has something rather more mundane in mind, perhaps nothing more than that it is the state of one's soul at death that determines whether one is destined for rewards or punishments in the afterlife, with the "good" and "bad" souls thereafter following different paths. $^{77}$

\footnotetext{
${ }^{73}$ Leibniz to Queen Sophie Charlotte (1702), G VI, 522/LTS 296.

${ }^{74}$ G VII, 330/SLT 65; G VI, 609/LM 275.

${ }^{75}$ See for example "Letter on what is independent of sense and matter" (1702), G VI, 507/LTS 245; New Essays on Human Understanding (1703-1705), A VI 6, 221/NE 221.

${ }^{76} \mathrm{G}$ VI, 436/H 441.

${ }^{77}$ This of course entails that one's fate is essentially fixed by the state of one's soul at death, such that a soul which is damned (for example) does not become un-damned by turning over a new leaf in the afterlife. And this
} 
But the Wagner letter does reveal one way in which rewards and punishments might be distributed in the future life: by genii, that is, angels and demons. That Leibniz should have recourse to angels and other genii to facilitate the harmony between the two kingdoms is fully consistent with what he says about their role elsewhere. In the Theodicy, for example, Leibniz claims that "God employs the ministry of angels in order to govern mankind, without the order of nature suffering thereby" ${ }^{78}$ Leibniz is able to count the actions of angels as part of the natural order, rather than as a deviation from it, because of the sharp distinction he draws between the nature of created beings (that is, finite substances), and the nature of God. ${ }^{79}$ Those actions of created beings which are in accordance with their own natures are squarely part of the order of nature. This order is disturbed only by those actions of created beings which are beyond their own natures (for which they must be assisted by God). Leibniz in fact recognizes very few such actions, ${ }^{80}$ and certainly the normal actions of genii are not among them. Thus the normal actions of genii fall within the order of nature, and so are not genuinely supernatural or miraculous.

But while Leibniz is happy to tell Wagner that angels and demons administer rewards and punishments, he is silent about how and when this happens. We might surmise, on the basis of Leibniz's insistence that a great many rewards and punishments are deferred to the afterlife, that many of their rewarding and punishing operations occur at that time, though one should not rule out the possibility that some occur in this life also. ${ }^{81}$ After all, the idea that God uses "punishing angels" or "avenging angels" to punish sin in this life is found

is in fact Leibniz's position; he says in the Theodicy: "there is always in the man who sins, even when he is damned, a freedom which renders him culpable, and a power, albeit remote, of recovering himself, although it never passes into action". G VI, 277/H 292.

${ }^{78}$ G VI, 434/H 439.

${ }^{79}$ See for example Leibniz to Sophie (23 October/2 November 1691), A I 7, 46-47/LTS 88.

${ }^{80}$ His stock example of this is prophecy: genuine knowledge of future events (as opposed to a guess), requires knowledge of an infinity of causes, which is consistent with God's nature but not that of humans or any other finite substance. Thus any genuine case of human prophecy must involve God's inspiration or assistance, and thereby be straightforwardly supernatural, involving as it does actions that are beyond the natures of all finite substances. See Cook 2009, 269-287.

${ }^{81}$ One might see a problem here, in that while an angel may well be happy to carry out God's bidding, and administer punishments in the interests of justice, a demon would not. Nevertheless, demons have been thought to torment individuals for their own reasons, which allows these torments to be considered as punishments. Hence Anselm supposed that humans tormented by the devil are undergoing just punishment, even though the devil torments out of malice, rather than justice. See Anselm 1962, I.7. 
throughout the Old and New Testaments, ${ }^{82}$ and was widely endorsed by early modern thinkers (such as Malebranche) ${ }^{83}$ My own suspicion, however, is that Leibniz supposed that whatever punishments are meted out in this life, are done so through a different method, namely personal misfortunes that were calculated to occur naturally following a sinful act. We thus turn now to that.

Historically, of course, it has often been thought that misfortunes in this life are often punishments from “on high" for one's misdeeds, a view with which Leibniz concurred. In a text from the 1690s we find Leibniz posing the question "whether unfortunate outcomes really and truly are due to sins", ${ }^{84}$ that is, punishments for those sins, and after much deliberation he finally concludes - on the basis of God's wise government of the universe that "it should be considered most certain that misfortune after wickedness is to be ascribed to that wickedness". ${ }^{85}$ The misfortunes Leibniz has in mind are ones that arise not from a direct intervention by God (such as a lightning bolt), but rather from "some infallible calculation," ${ }^{, 86}$ where the misfortune was arranged from the very beginning of things so that it would occur naturally at a morally pertinent time. We are to construe this in terms of God's skilful arrangement of people, places, and events, to ensure that misfortunes follow sinful actions. In such cases, the misfortunes were built into the plan of the universe at the outset, to enable the physical and moral orders to coincide.

Leibniz was by no means alone in holding such a view. Malebranche, in his Dialogues on Metaphysics and on Religion (1688), had earlier insisted that

infinitely more wisdom is required to combine the physical and the moral in such a way that certain people are justly punished for their misdeeds as a consequence of the series of causes, than is required to punish them by means of a particular and miraculous providence. ${ }^{87}$

Malebranche illustrates how the physical and the moral can come together in this way with the example of a villain who dies of fever; although low-key, the example shows divine justice working through the natural order, as opposed to divine justice intervening in and

\footnotetext{
${ }^{82}$ See for example 2 Kings 19.35, 1 Chronicles 21.15, Matthew 13.49-50, Acts 12.23, and Revelation 8.

${ }^{83}$ See for example Malebranche 1685, 28, cf. 42-43.

84 "Can the bad outcomes of wicked actions be ascribed to wickedness?" (1696-1697), Gr I, 372/SLT 204.

${ }^{85}$ Gr I, 374/SLT 207.

${ }^{86}$ Gr I, 373/SLT 206.

${ }^{87}$ Malebranche 1997a, 245 (XIII.III).
} 
disrupting the natural order (which is what would happen if the villain were to be struck down by a lightning bolt sent from heaven). ${ }^{88}$ Leibniz himself does not offer any examples of this kind of orchestrated punishment, but presumably any naturally-occurring misfortune that follows a wicked act will suffice. ${ }^{89}$ Leibniz is at pains to stress, however, that not all misdeeds are followed by misfortunes, and further, that the reasons for this must be sought in the moral order rather than the natural order. That is, if a sinner does not experience a misfortune soon after the commission of a sinful act, this is because there were pressing moral reasons that prevented the immediacy of punishment in this case, and not because God was unable to arrange a misfortune through the natural order. In cases such as these - and there are many, Leibniz concedes - punishment is deferred to the future life (where, as we know, it will likely be carried out either through human psychology, or the ministry of genii). Nevertheless, the fact that God is prompted to orchestrate misfortunes by the sins of the wicked means that this form of natural punishment is squarely agential in character, since the sins have quite literally attracted punishment from God.

\section{Conclusion}

As we have covered a lot of ground, a summary of our findings would be worthwhile. As we have seen, Leibniz's harmony between the kingdoms of nature and grace is a compound of various doctrines, which may be summarized as follows:

\footnotetext{
${ }^{88}$ Malebranche 1997a, 244 (XIII.III).

${ }^{89}$ It may be objected that the misfortune cannot be considered a true punishment because the person on the receiving end would not know (a) that it is a punishment (as opposed to plain bad luck), and (b) what it is a punishment for. Leibniz's response is that punishment does not require the one being punished to know that he is being punished: "If we are to speak quite generally of punishment [...] there are grounds for questioning whether it is absolutely necessary that those who suffer should themselves eventually learn why, and whether it would not quite often be sufficient that those punishments should afford, to other and better informed Spirits, matter for glorifying divine justice." Leibniz then continues to say "Still, it is more likely, at least in general, that the sufferers will learn why they suffer", though he neglects to say when they will learn this. Consequently, it might only be in the afterlife that a person comes to learn that such-and-such a misfortune endured in this life was punishment for such-and-such a sin. See A VI 6, 246/NE 246.
} 


\begin{tabular}{|c|c|c|}
\hline Doctrine & Details & \\
\hline $\begin{array}{l}\text { (HG1) The order of } \\
\text { nature makes possible } \\
\text { the rewards and } \\
\text { punishments of } \\
\text { rational souls }\end{array}$ & $\begin{array}{l}\text { All souls are naturally indestructible. } \\
\text { Rational souls also naturally preserve } \\
\text { their memory and personality. }\end{array}$ & \\
\hline & & $\begin{array}{l}\text { Form of natural punishment } \\
\text { involved }\end{array}$ \\
\hline $\begin{array}{l}\text { (HG2) The rewards } \\
\text { and punishments of } \\
\text { rational souls are } \\
\text { administered naturally }\end{array}$ & $\begin{array}{l}\text { Distancing oneself from God is its own } \\
\text { punishment } \\
\text { The effects of original sin were } \\
\text { transmitted naturally } \\
\text { The great flood occurred naturally at the } \\
\text { time when morally it was required } \\
\text { The great conflagration will occur } \\
\text { naturally at the time when morally it is } \\
\text { required } \\
\text { The rewards and punishments of each } \\
\text { individual human being will be } \\
\text { administered naturally, namely: } \\
\text { - Through normal human } \\
\text { psychology (?) } \\
\text { - Through the operations of genii } \\
\text { Through the skilful arrangement } \\
\text { of people, places, and events, to } \\
\text { ensure that misfortunes follow } \\
\text { sinful actions }\end{array}$ & $\begin{array}{l}\text { Reflexive } \\
\text { Nomic } \\
\text { Nomic } \\
\text { Nomic }\end{array}$ \\
\hline
\end{tabular}

As we have seen, although the notion of the harmony between the two kingdoms only appears in Leibniz's work in 1710, the doctrines it encompasses were part of his philosophy earlier than that: HG1 in the 1680s, and HG2 in the 1690s. ${ }^{90}$ Although it is difficult to

\footnotetext{
${ }^{90}$ It is noteworthy that none of the elements of the harmony between the two kingdoms are to be found in the Discourse on Metaphysics of 1686 . With regard to HG1, while Leibniz does state in $\S 34$ and $\S 36$ of the Discourse that souls are immortal, he does not indicate whether this is achieved naturally or supernaturally; however, it is the latter that looks to be suggested when in $\S 35$ he claims that "God will always preserve not
} 
speculate on Leibniz's reason for compounding these doctrines, it should be noted that they are complementary, together representing the specifically historical dimension of his theodicy, at least insofar as it pertains to human beings, for it is through the mechanisms described in these doctrines that history moves to align the moral world with the natural world.

Leibniz thus sees the harmony between the kingdoms of nature and grace as concerned with divine justice, and indeed exclusively so, since he makes no further claims for this harmony; that is, he does not identify any examples of the harmony beyond those identified above, all of which concern divine justice. This might be thought surprising, inasmuch as it would mean that the harmony between the kingdoms of nature and grace does not have anything at all to do with grace. And indeed, it is notable that when Leibniz discusses this harmony he does not ever discuss grace (and its distribution) in connection with it. ${ }^{91}$ And this is in spite of the fact that Leibniz did hold that God's particular grace (that is, the grace granted to a particular individual, as opposed to his general grace, which is granted to all) is distributed by natural means, rather than through ad hoc divine interventions. To understand what is involved in this, consider an example developed by Malebranche, of two people, one of whom wishes to go to the opera, while the other wishes to hear a preacher. Now if both do as they wish, the former will encounter in the opera certain ideas that will ruin him, while the latter will encounter in the preacher such wisdom as to convert him. But as it happens, a natural event - a rain shower - intervenes, and prevents both from going out. Malebranche insists that this natural event may be deemed a grace by the first (since it prevents his ruin), and a punishment by the latter (since it prevents his conversion). According to Malebranche, divine providence often works this way, distributing its grace through natural effects, rather than through ad hoc interventions that would upset the order of nature. ${ }^{92}$ Leibniz promoted a similar view. In an early writing, from 1676, he

only our substance but also our person.” As for HG2, while Leibniz stresses in $\S 34$ and $\S 36$ of the Discourse that minds are capable of reward and punishment, he says nothing about how these are to be administered. See A VI 4, 1583-1587/L 325-327.

${ }^{91}$ Of course, some of the writings from Leibniz's later years have yet to be published, so it is possible that there does exist in the Hanover archives one or more texts in which Leibniz explicitly discusses the connection between his doctrine of grace on the one hand, and the harmony of the kingdoms of nature and grace on the other. But on the basis of the work that has been published thus far, there is no reason to believe that any such text exists.

${ }^{92}$ See Malebranche 1680, 145-147. 
suggests that grace was factored into creation right from the outset, such that direct interventions by God were not required for its distribution. ${ }^{93}$ This led him to construe particular grace as primarily a fortunate concurrence of events that cause or inspire a good will. To one correspondent he explains that a young woman's visions of Christ can be explained naturally, being the result of her intense love of God, itself inspired by her religious upbringing, and are nevertheless to be considered a grace because they reinvigorate her piety. ${ }^{94}$ Consistent with this thought, in the Theodicy Leibniz repeatedly stresses the importance of one's circumstances in determining whether one is saved or damned, and that finding oneself in a favorable circumstance may be considered a grace. ${ }^{95}$ As the placing of favored individuals in favorable circumstances could have been arranged by careful planning right at the outset, we can be assured that this is what God would have done; after all, a wise creator would choose the efficient method of grace distribution, via natural means, over the more profligate method, of numerous ad hoc interventions. ${ }^{96}$ Nevertheless, although this would seem to be a clear case of nature harmonizing with grace, Leibniz does not identify it as part of his harmony between the kingdoms of nature and grace. Why should this be?

We can find no explicit answer to this in Leibniz's writings, but the following observations are surely relevant. First, Leibniz is clear that the harmony in question holds between the kingdom of nature and the kingdom of grace, and not between nature and grace per se. And by "the kingdom of grace" Leibniz means only "the divine city of minds". ${ }^{97}$ Second, as we have noted, the harmony between the two kingdoms appears to be concerned exclusively with divine justice. If this is how Leibniz understood it, as seems to be the case, then it is not surprising that he would not mention grace in connection with it, since of course grace is not a matter for God's justice: grace is, after all, neither a reward nor a punishment, but rather an unmerited gift. Moreover, Leibniz may not have been willing to expand the harmony between the two kingdoms to encompass grace and its distribution because although he held that God's particular grace was distributed naturally, it also seems that he wished to recognize (or at least allow for) other forms of grace more supernatural in character. Nowhere is this clearer than in his commentary on Gilbert Burnet's Thirty Nine Articles of the Church of England. In his commentary, written in 1705, Leibniz makes frequent reference to grace

\footnotetext{
93 "On the secrets of the sublime" (11 February 1676), A VI 3, 477/DSR 31.

${ }^{94}$ See Leibniz to Sophie (13/23 October 1691), A I 7, 34/LTS 77.

95 See for example G VI, 158-160/H 178-179.

${ }^{96}$ For further details on this, see Rutherford 2014, 71-91.

${ }^{97}$ G VI, 622/LM 32.
} 
that is distributed naturally (by individuals being placed in fortunate circumstances), but he also refers to "a certain special type of grace" only for the Elect, ${ }^{98}$ makes a distinction between "supernatural internal grace and natural and external aids", ${ }^{99}$ refers to "single operation particular causes" in the matter of grace, ${ }^{100}$ and insists that "grace is brought to us in the natural and ordinary way and in the extraordinary and miraculous way". ${ }^{101}$ When these remarks are placed alongside the rather more numerous statements about the natural distribution of grace, it is far from certain that Leibniz personally believed that much if any grace was distributed supernaturally, that is, by direct interventions from God, but it does seem reasonable to suppose that at the very least he wished to leave open the possibility that some grace was distributed that way. Consequently, if Leibniz did want to allow that some grace was supernatural in origin, it is not difficult to see why he would be reluctant to bring grace (and its distribution) within the purview of the harmony between the kingdoms of nature and grace, which is itself concerned with God's moral ends being carried out by natural means. As such, nothing supernatural in origin can fall under this doctrine, whether rewards, punishments, or grace. Ultimately, then, we should not be surprised that Leibniz's harmony between the two kingdoms makes no reference to grace.

As a final thought, it is worth highlighting the fact that the belief that there is a harmony between the natural realm and moral realm was hardly unique to Leibniz; in fact, as we have seen, all of the constituent elements of Leibniz's harmony are to be found in the work of one of his contemporaries, Nicolas Malebranche, though Malebranche stopped short of endorsing them all (specifically, he rejected the natural occurrence of the great flood and final conflagration). The similarity between Malebranche's position and that later developed by Leibniz is striking, though claims of direct influence are likely to be overblown (due to the relatively broad popularity of the doctrines involved) and shall not be made here. ${ }^{102}$ Suffice it to say, although the package of doctrines known to us as the harmony of the kingdoms of

\footnotetext{
98 DNG 59.

99 DNG 59.

${ }^{100}$ DNG 61.

101 DNG 99.

${ }^{102}$ One might also see shades of Spinoza in Leibniz's harmony between the two kingdoms, inasmuch as the Dutchman likewise rejected the idea of an external system of rewards and punishments (albeit for an entirely different reason), and taught that virtue brings about its own reward. However, Spinoza could not have accepted any of the constituent elements in Leibniz's harmony.
} 
nature and grace was almost entirely foreshadowed in Malebranche, it would be wrong to think of it as anything other than distinctly Leibnizian. ${ }^{103}$

\section{Works by Leibniz}

A Sämtliche Schriften und Briefe. Eds. Berlin-Brandenburgische Akademie der Wissenschaften. Berlin. 1923-. Multiple volumes in 8 series, cited by series (reihe) and volume (band).

AG Philosophical essays. Trans. and ed. R. Ariew and D. Garber. Indianapolis 1989.

C Opuscules et fragments inédits de Leibniz. Ed. L. Couterat. Paris 1903.

CP Confessio Philosophi. Trans. and ed. R. C. Sleigh Jr. New Haven 2005.

CW Protogaea. Trans. and ed. C. Cohen and A. Wakefield. Chicago 2008.

D G. G. Leibnitii Opera Omnia. Ed. L. Dutens, 6 vols. Geneva 1768.

DNG Dissertation on Predestination and Grace. Trans. M. Murray. New Haven 2011.

DSR De summa rerum. Trans. G. H. R. Parkinson. New Haven 1992.

G Die Philosophischen Schriften von Gottfried Wilhelm Leibniz. Ed. C. I. Gerhardt. 7 vols. Berlin 1875-1890.

Gr Textes inédits. Ed. G. Grua. 2 vols with successive pagination. Paris 1948.

H Theodicy. Trans. E. M. Huggard. Ed. A. Farrer. Chicago 1990.

K Die Werke von Leibniz. Ed. O. Klopp. 11 vols. Hanover 1864-1884.

L Philosophical Papers and Letters. Trans. and ed. L. E. Loemker. Dordrecht 1969.

LM Leibniz's Monadology. Trans. and ed. L. Strickland. Edinburgh 2014.

LTS Leibniz and the Two Sophies. Trans. and ed. L. Strickland. Toronto 2011.

NE New Essays concerning Human Understanding. Trans. and ed. P. Remnant and J. Bennett. Cambridge 1996.

P Philosophical Writings. Trans. M. Morris and G. H. R. Parkinson. Ed. G. H. R. Parkinson. London 1973.

R Political Writings. Trans. and ed. P. Riley. Cambridge 1988.

SLT Shorter Leibniz Texts. Trans. and ed. L. Strickland. London 2006.

${ }^{103}$ I would like to offer my thanks to Daniel J. Cook, Nicholas Jolley, and two anonymous referees for their suggestions on a previous version of this paper, as well as to Peter Clarke and Shandon Guthrie for their helpful discussion on the general topic. I am also indebted to Donald Rutherford, Ursula Goldenbaum, and Christopher Bobier for their constructive comments on a previous version of this paper, which was read at the Leibniz Society for North America conference held 31 October - 2 November 2014, at the University of South Florida, Tampa. 
W Briefwechsel zwischen Leibniz und Christian Wolff. Ed. C. I. Gerhardt. Halle 1860.

Adams, R. M. 1994. Leibniz: Determinist, Theist, Idealist. Oxford.

Anselm. 1962. Cur Deus homo. In Basic Writings. Trans. S. N. Deane. Chicago: 191-302.

Augustine. 1956. On Marriage and Concupiscence. In St. Augustine's Anti-Pelagian Works.

Ed. P. Schaff. Grand Rapids: 758-885.

Augustine. 2012. The Confessions. Trans. M. Boulding O.S.B. San Francisco.

Broad, C. D. 1975. Leibniz: An Introduction. Cambridge.

Burnet, T. 1681. Telluris Theoria Sacra. London.

Carlin, L. 2002. "Reward and punishment in the best possible world". The Southern Journal of Philosophy 60: 139-160.

Cook, D. J. 2009. “Leibniz on 'prophets', prophecy, and revelation”. Religious Studies 45: 269-287.

Descartes, R. 1984. The Philosophical Writings of Descartes Volume II. Ed. J. Cottingham, R. Stoothoff and D. Murdoch. Cambridge.

Fabre, J. 1907. La pensée moderne de Luther à Leibniz. Paris.

Garber, D. 1995. "Leibniz: physics and philosophy”. In The Cambridge Companion to

Leibniz. Ed. N. Jolley. Cambridge: 270-352.

Hick, J. 2010. Evil and the God of Love. New York.

Kant, I. 1996. Critique of Practical Reason. Trans. Thomas Kingsmill Abbott. New York.

Le Grand, A. 1678. Institutio philosophiae secundum Principia d. Renati Descartes. London.

Malebranche, N. 1680. Traité de la Nature et de la Grace. Amsterdam.

Malebranche, N. 1683. Meditations chrestiennes. Cologne.

Malebranche, N. 1685. Réponse à une dissertation d'Antoine Arnauld contre un

eclaircissement du Traité de la Nature \& de la Grace. Rotterdam.

Malebranche, N. 1997a. Dialogues on Metaphysics and on Religion. Trans. N. Jolley and D.

Scott. Cambridge.

Malebranche, N. 1997b. The Search after Truth. Trans. T. M. Lennon and P. J. Olscamp. Cambridge.

Mormino, G. 2009. "Peines humaines et peines divines. Théodicée et droit de punir dans la pensée de Leibniz". In L'idéé de Théodicée de Leibniz à Kant: Heritage, Transformations, Critiques. Ed. P. Rateau. Stuttgart: 37-50.

Otreb, R. [pseudonym: Robert Fludd]. 1617. Tractatus Theologo-Philosophicus. Oppenheim. 
Phemister, P. 2003. "Exploring Leibniz's kingdoms: a philosophical analysis of nature and grace". Ecotheology 7: 126-145.

Ray, J. 1692. Miscellaneous Discourses Concerning the Dissolution and Changes of the World. London.

Rutherford, D. 2014. "Justice and circumstances: Theodicy as universal religion". In New Essays on Leibniz's Theodicy. Eds. L. M. Jorgensen and S. Newlands. Oxford: 71-91. Savile, A. 2000. The Routledge Philosophy Guidebook to Leibniz and the Monadology. London.

Seneca. 1786. The Epistles of Lucius Annaeus Seneca. Vol. II. Ed. Thomas Morell. London. Sève, R. 1989. Leibniz et l'école modern du droit naturel. Paris.

Smith, J. E. H. 2011. Divine Machines: Leibniz and the Sciences of Life. New Jersey. Tertullian. 1873. A Treatise on the Soul. In Ante-Nicene Fathers Volume 3. Eds. A. Robertson and J. Donaldson. Edinburgh: 181-235.

Voltaire. 2006. Candide and Other Stories. Trans. R. Pearson. Oxford.

Woolhouse, R. 2011. Starting with Leibniz. London.

Zangger, C. D. 1973. Welt und Konversation: Die theologische Begründung der Mission bei Gottfried Wilhelm Leibniz. Zürich. 